\title{
Prevalence of Different Types of Micro-Organisms and Levels of Complement C5a in Patients with Acute-Phase Wound Infections
}

\author{
Mohemid M. Al-Jebouri', Balsam Yahya R. Al-Mahmood² \\ ${ }^{1}$ Department of Microbiology, College of Medicine, University of Tikrit, Tikrit, Iraq \\ ${ }^{2}$ Department of Microbiology, College of Veterinary Medicine, University of Mosul, Mosul, Iraq \\ Email: profaljebouri@yahoo.com
}

How to cite this paper: Al-Jebouri, M.M. and Al-Mahmood, B.Y.R. (2019) Prevalence of Different Types of Micro-Organisms and Levels of Complement C5a in Patients with Acute-Phase Wound Infections. Open Journal of Pathology, 9, 19-28.

https://doi.org/10.4236/ojpathology.2019.9 $\underline{2003}$

Received: January 28, 2019

Accepted: March 31, 2019

Published: April 3, 2019

Copyright $\odot 2019$ by author(s) and Scientific Research Publishing Inc. This work is licensed under the Creative Commons Attribution International License (CC BY 4.0).

http://creativecommons.org/licenses/by/4.0/

cC) (7) Open Access

\begin{abstract}
Background: An acute wound infection might be caused by external damage to the skin including abrasions, lacerations, bites, burns, accidents, war injuries and surgical incisions. When a wound fails to heal within a week, it should be considered a chronic type. Complement system potent inflammatory cascade in wound infection, is important and altered wound healing. Complement activation leads to the generation of many potent effectors including anaphylatoxin C5a. C5a has induced synthesis of TNF- $\alpha$ and IL- $1 \beta$ in macrophage and monocyte which are all together the goal of the present paper. Methodology: This study was conducted in Al-Kindy and Al-Wasity hospitals in Baghdad on 200 patients suffering from wounds. One hundred patients were with acute wounds infection and the other 100 patients considered as control wounds i.e. without infection. The procedure method was followed according to manufacturer's instructions (Elabscience, USA) utilizing C5a ELISA kit for conducting the test. Blood samples were taken at 24, 48, 72, 96 and 120 hours of hospitalization of the patients. Results: It was found that the highest concentration of $\mathrm{C} 5 \mathrm{a}$ was found at 120 hours after patients hospitalization who were with wound infection, and the mean value of $\mathrm{C} 5 \mathrm{a}$ was $4898 \mathrm{pg} / \mathrm{ml} .4661 \mathrm{pg} / \mathrm{ml}$ of C5a was recorded among patients with acute-phase infection compared to $4387 \mathrm{pg} / \mathrm{ml}$ concentration of the same complement among control group without wound infection at 96 hours post residence in hospital. Conclusions: Gram-positive bacteria were more prevalent causing wound infections. Dermacoccus nishinomiyaensis, Kocuria rosea and Kocuria kristinae were isolated for the first time in this locality. A complement $5 \mathrm{a}(\mathrm{C} 5 \mathrm{a})$ revealed a very high concentration in acute-phase of wound
\end{abstract}


infections. It was found that C5a was serially elevated with time of hospitalization of wounded and infected patients. C5a was highly elevated with wound infection by Gram-negative bacteria compared to infections by Gram-negatives.

\section{Keywords}

Acute-Phase Wounds, Complement 5a, Patients, Iraq

\section{Introduction}

Wound infection is invasive with pathogen to a level that invokes local and systemic response host. Presence of pathogen causes delayed wound healing. Bacteria are one of the most important pathogens contaminated wound and cause infection [1]. The wounds are commonly colonized by Staphylococcus aureus within the first week and later by Pseudomonas aeruginosa and other Enterobacteriaceae like Escherichia coli, Klebsiella sp, and Proteus mirabilis. All these events usually lead to stimulation of innate immune system and play a role in acute inflammation [2]. Complement system potent inflammatory cascade in wound infection, is important and altered wound healing [3]. Complement activation leads to the generation of many potent effectors including anaphylatoxin C5a [4], which is important for leukocyte recruitment and activation [5]. The activity of the anaphylatoxins is regulated by carboxypeptidase $\mathrm{N}$ which is present in tissues [6]. C5a has induced synthesis of TNF- $\alpha$ and IL- $1 \beta$ in macrophage and monocyte [7]. Thrombin and plasmin resulted in release of C5a and C3a possessed significant chemotactic activity for neutrophils in inflammatory pathway [8]. C5a is playing a role as Chemoattractant of macrophage and neutrophil to the site of inflammation, also induces increase oxidative burst, phagocytosis and release of granule enzyme. Allergy inducing C5a and production of huge amounts of histamine will lead to dilatation of blood vessels to facilitate passage of large size and number of leucocytes toward site of infection.

Among activation of $\mathrm{C} 5$ to generation of the C5a thereby assembly of membrane attack complex given prominent the role of $\mathrm{C} 5 \mathrm{a}$ in septic patients [9].

\section{Materials and Methods}

\subsection{Patients}

The study was conducted at AL-Wasity and AL-Kindy hospitals of Baghdad city from December 2017 to August 2018. The number of patients was 100 Patients who were with infected wound due to sign of inflammation (acute wounds infection) like: surgical wounds, burn wounds, laceration, abrasions, cut and bites, and 100 patients included as control groups who had wounds without infection. All patients with acute was surveyed for clinical sign like erythema, malodour, pain, heat and exudate. Ethical clearance for the study was obtained from the Committee of Higher Studies in College of Medicine, University of Tikrit. 


\subsection{Isolation and Identification of Bacteria}

Before taking a wound swab, the wound was gently cleaned with sterile gauze, rotate the swab over a one $\mathrm{cm}$ area of the wound, applying sufficient pressure to express fluid from the wound bed [10] [11]. After sampling, each swab was applied on to blood and MacConkey agars and incubated for $24 \mathrm{~h}$ at $37^{\circ} \mathrm{C}$ under aerobic condition. Colonies were identified by Gram's staining [12] differentiated, and identification by API 20E, and VITEK-2 compact system (bioMerieux Deutschland, Nurtingen, Germany).

\subsection{Complement C5a Estimation}

Five milliliters of blood was collected by vein puncture using disposable syringe. Blood samples were placed into plan tube for 15 - 30 at room temperature to clott, then were centrifuge for 5 minutes at $3000 \mathrm{rpm}$ for serum separation. Sera were stored at $-70^{\circ} \mathrm{C}$ for further studies [13] [14]. ELISA kits were used utilizing sandwich ELISA principle. The optical density (OD) is measured spectrophotometrically at a wavelength of $450 \mathrm{~nm}$ according to manufacturer instructions.

\subsection{Statistical Analysis}

F-test utilizing ANOVA computer program was used for data analysis and the significance was considered at $\mathrm{P}$ value of less than 0.05 .

\section{Results}

The present study on acute-phase wound infection revealed that 17 bacterial types were isolated and identified (Table 1). A highest frequency of isolation was recorded with Staphylococcus aureus which was 30/105 (28.6\%) whereas the lowest frequency was seen with Morganella morganii spp morganii (1\%).

Gram positive bacteria were the most common isolates (53.30\%). Gram-negatives were also isolated from different infected wounds and the most prevalent pathogen was Acinetobacter baumannii (Table 1). The present study revealed a mixed culture with frequency of $8.60 \%$ (Table 1, Figure 1).

The present study showed that C5a concentration was increased with time of residence of patient with wound infections e.g., the C5a concentration was 4113 $\mathrm{pg} / \mathrm{ml}$ at the end of the second day of residence, and this value was elevated to be $4898 \mathrm{pg} / \mathrm{ml}$ at 120 hours of hospitalization (Figure 2). The C5a concentration estimation among control patients was decreased with the time of residence in hospital, e.g. the C5a concentration was $4699 \mathrm{pg} / \mathrm{ml}$ after 48 hours of residence and this value started to decrease at 96 hours of hospitalization to be $4387 \mathrm{pg} / \mathrm{ml}$ (Figure 3). A statistical analysis using F-test showed significant differences of the values estimated $(\mathrm{P}<0.05)$.

The present study revealed that among 100 patients 40 were with acute-phase wound infection by Gram-negative bacteria and the mean value of the C5a in their sera was $4686.2 \mathrm{pg} / \mathrm{ml}$. Whereas $56 / 100$ patients were infected with Gram-positive bacteria and the mean value of the same complement was lower 
Table 1. Distribution of gram positive and gram negative isolates.

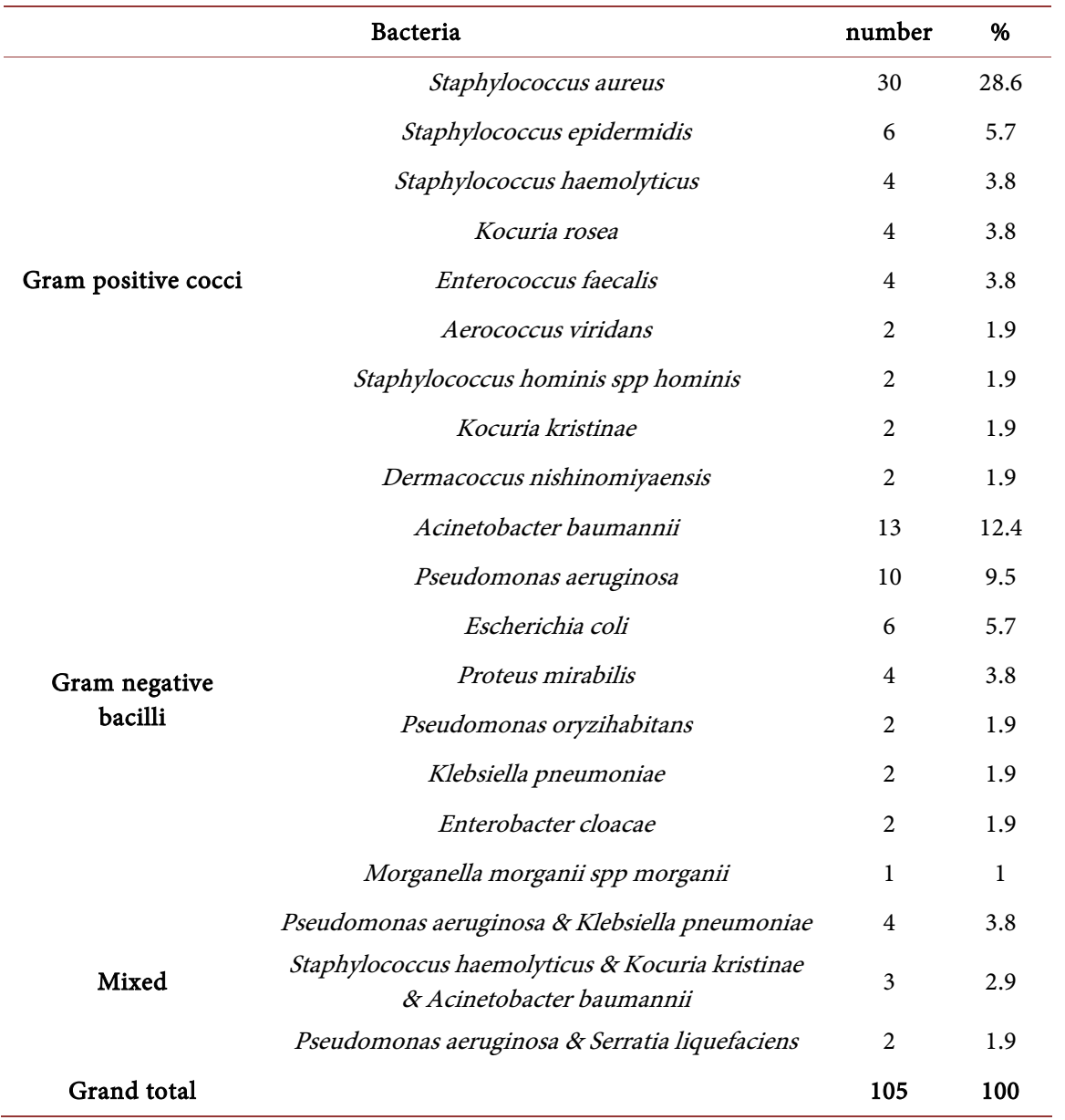

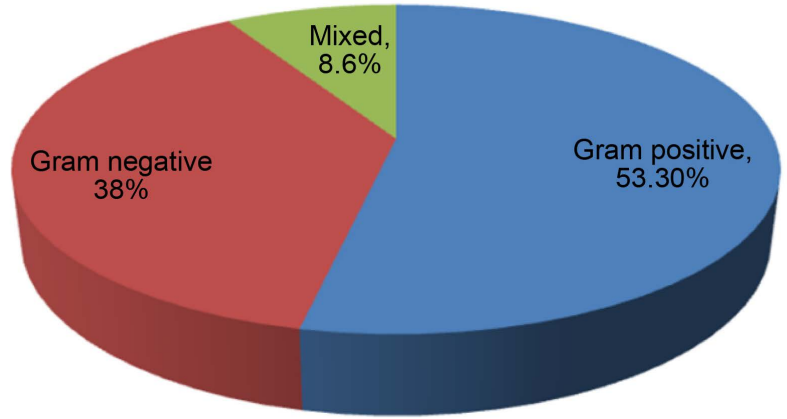

Figure 1. Isolation frequency of Gram-positive, Gram-negative and mix bacteria.

compared to those infected with Gram-negative bacteria i.e. the mean value was $4546.8 \mathrm{pg} / \mathrm{ml}$ i.e. Gram-negatives induced higher amount of C5a compared to Gram-positive pathogens (Figure 4). Statistical analysis revealed a significant difference between these values $(\mathrm{P}<0.05)$.

\section{Discussion}

The present study revealed that Staphylococcus aureus was more prevalent 


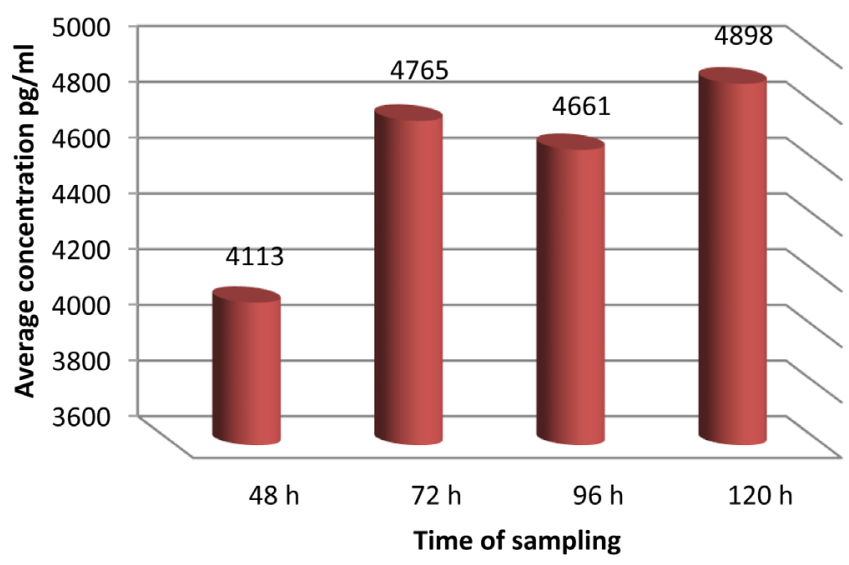

Figure 2. Values of C5a estimated at different times of stay of patients in hospital with acute-phase wound infections.

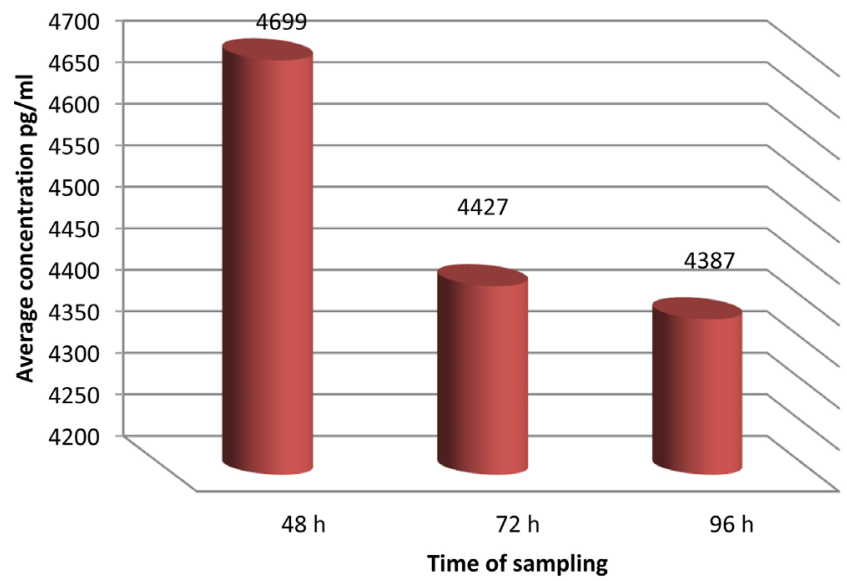

Figure 3. Values of C5a estimated at different times of stay of patients in hospital without wound infections.

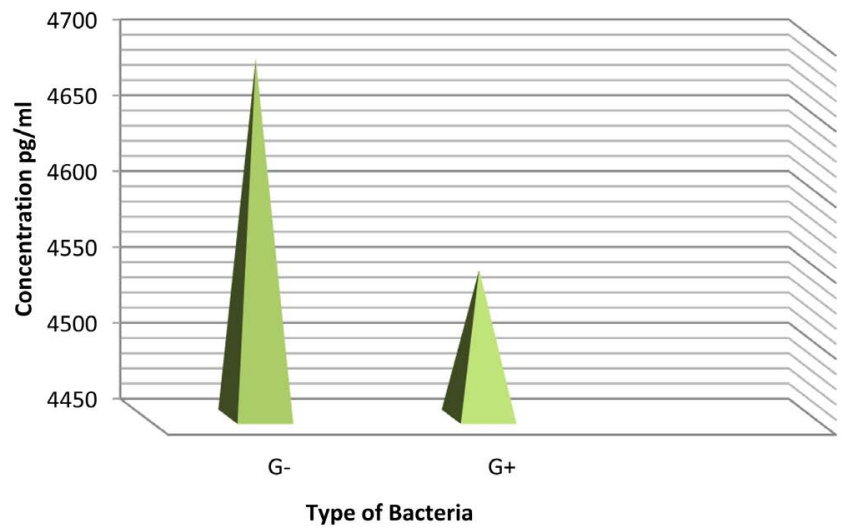

Figure 4. Values of C5a in relation to types of bacterial infection of acute-phase wounds. G-, Gram-negative bacteria; G+, Gram-positive bacteria.

causing acute-phase wound infection and the frequency of isolation was $28.6 \%$ This result was almost similar to that obtained by Nagoba and others who found 
that the incidence of this bacteria was $28.12 \%$ [14] [15] and Yin (2013) who showed Staphylococcus aureus was responsible for the majority of skin and soft tissue infection. $S$. aureus causes invasive and life threatening infection such as abscesses, and sepsis [16]. Others workers concluded different frequencies of isolation e.g. Rajan showed that $44.6 \%$ of the wounds studied were infected by $S$. aureus [17]. Almost 25\% of the infections recorded in the present study were collectively caused by other Gram-positive bacteria which was almost similar to that obtained by Alwan and his co-workers [18]. Dermacoccus nishinomiyaensis, Kocuria rosea and Kocuria kristinae were isolated for the first time among patients of Baghdad district. However, the pathogens were also recorded elsewhere [19]-[24]. Therefore, these new isolated bacteria should be considered as a true pathogen contributed to clinical sepsis and proper treatment should be provided to all susceptible patients [19] [20]. Moreover, isolation of Kocuria kristinae with others bacteria was similar to that obtained by some authors who recorded K. kristinae as commensal of humans, animal and environment to be contaminants of wounds [21] [22]. In the present study, among the Gram negatives, Acinetobacter baumannii was isolated with the highest frequency $(12.4 \%)$ followed by Pseudomonas aeruginosa (9.5\%) from the total isolates of wound and the two types were isolated by Al-Ali who found that the isolation frequencies by both were $19.5 \%$ and $39.5 \%$ respectively [25]. E. coli was isolated with percentage of $5.7 \%$ which was different from that obtained by Rashid et al. who showed almost $2 \%$ of their isolates from wounds was $E$. coli [26]. In contrast, Idomir et al. estimated an incidence of by $E$. coli to be $11.5 \%$ [27] [28]. The isolation patterns of the other pathogens showed different frequencies compared to other workers [18] [27] [28] [29].

The present study revealed that complement C5a was very high in concentration at 120 hours of patient residence in hospital with average value of 4898 $\mathrm{pg} / \mathrm{ml}$ followed by $4765 \mathrm{pg} / \mathrm{ml}$ at 48 hours in acute-phase wound infection The most receptive interpretation that the mechanisms of accelerated healing were associated with lack of $\mathrm{C} 5 \mathrm{aR} 1$ signaling, and $\mathrm{C} 5 \mathrm{a}$ as well as reduced recruitment of inflammatory cells to wounds along with their reduced activation. The increased angiogenesis and high levels of mast cells contribute to more efficient healing process [30]. The same opinion concluded by Rafail and co-workers who showed that C3 and C5 deficiency revealed a reduction in inflammatory and increased accumulation of mast cells and advanced angiogenesis [31]. The increased C5a after $48 \mathrm{hrs}$ in the wounds mentioned by Jang and co-workers showed that after wounds infection the activation of complement system, split fragment C5a and C3a augment inflammatory responses e.g. increased blood flow and vascular permeability and facilitate migration of neutrophils and monocytes to the inflamed tissue also induce mast cell to release histamine and TNF- $\alpha$ which contribute to the proliferation of the inflammatory response. C5a has the ability to stimulate cells to secrete neuropeptides and neurotrophins as the main roles of pain after wounds as well as C5a sensitized C-fiber afferent response to heat in the incision, as noted C5a concentration $1000 \mathrm{pg} / \mathrm{ml}$ at $24 \mathrm{hrs}$ 
begins to decline at $48 \mathrm{hrs}$ with concentration $800 \mathrm{pg} / \mathrm{ml}$ in the clean wounds and present any infection may causes long wounds healing due to prolonged inflammatory process [32]. The elevated concentrations of C5a described in sepsis due to bacteria particularly Gram-negative types which showed a higher concentration of $\mathrm{C} 5 \mathrm{a}$ as compared to Gram-positive bacteria which revealed less elevation in this complement. $\mathrm{C} 5 \mathrm{a}$ is an important mediator of neutrophil dysfunction, acting via the major C5a receptor CD88, and CD88 is not directly phagocytic but is marker of exposure to C5a which inhibits phagocytosis [33] [34]. Finally, all workers have indicated that reduction of complement component and activation causes improve wound healing, for this reason may be the concentration in control wounds were less than acute-phase of wounds [34].

\section{Conclusion}

The present study revealed that most of acute-phase wound infections were caused by Gram-positive bacteria. Dermacoccus nishinomiyaensis, Kocuria rosea and Kocuria kristinae were isolated for the first time among patients of Baghdad district. Acute-phase wound infection by Gram-negative bacteria caused a higher elevation in C5a concentration of patients compared to infection by Gram-positive types.

\section{Ethical Approval}

Ethical clearance for the study was obtained from the Committee of Higher Studies in College of Medicine, University of Tikrit. The researcher did not in any way expose participants of the study to physical or psychological harm. Participation in the study was strictly voluntary with the informed consent of participants that guaranteed their right to privacy. All authors hereby declare that all experiments have been examined and approved by the appropriate ethics committee and have therefore been performed in accordance with the ethical standards laid down in the 1964 declaration of Helsinki.

\section{Limitations}

Single region data of displacement area is not generalized. For this reason a survey of the whole area can reflect the whole region should be done.

\section{Conflicts of Interest}

The authors declare no conflicts of interest regarding the publication of this paper.

\section{References}

[1] White, R.J. (2009) Wound Infection-Associated Pain. Journal of Wound Care, 18, 245-249. https://doi.org/10.12968/jowc.2009.18.6.42803

[2] Macleod, A.S. and Mansbridage, J.N. (2004) The Innate Immune System in Acute and Chronic Wounds. Advances in Wound Care, 5, 65-78.

https://doi.org/10.1089/wound.2014.0608 
[3] Daha, N.A., Banda, N.K., Roos, A., Beurskens, F.J., Bakker, J.M. and Daha, M.R. (2011) Complement Activation by (Auto-) Antibodies. Molecular Immunology, 48, 1656-1665. https://doi.org/10.1016/j.molimm.2011.04.024

[4] Van de Goot, F., Krjinen, P.A.J., Begieneman, M.P.V., Middelkoop, E. and Niessen, H.W.M. (2006) Acute Inflammation Is Persistent Locally in Burn Wounds: A Pivotal Role for Complement and C-Reactive Protein. Journal of Burn Care and Research, 30, 274-280. https://doi.org/10.1097/BCR.0b013e318198a252

[5] Cunnion, K.M., Krishna, N.K., Pallera, H.K., Fernandez, A.P., Rivera, M.G., Hair, P.S., Lassiter, B.P., Mary, A.C., Hood, A.F., Rodeheaver, G.T., Cottler, P.S., Jerry, L.N. and Dobrian, A.D. (2017) Complement Activation and STAT4 Expression Are Associated with Early Inflammation in Diabetic Wounds. PLOS ONE, 12, e0170500. https://doi.org/10.1371/journal.pone.0170500

[6] Markiewski, M.M. and Lambis, J.D. (2007) The Role of Complement in Inflammatory Diseases From Behind the Scenes into the Spotlight. The American Journal of Pathology, 171, 715-727. https://doi.org/10.2353/ajpath.2007.070166

[7] Burke-Gaffney, A., Blease, K., Hartnell, A. and Hellewell, P.G. (2002) TNF- $\alpha$ Potentiates C5a-Stimulated Eosinophil Adhesion to Human Bronchial Epithelial Cell: A Role for $\alpha_{5} \beta_{1}$ Integrin. The Journal of Immunology, 168, 1380-1388.

https://doi.org/10.4049/jimmunol.168.3.1380

[8] Amara, U., Flierl, M.A., Rittirsch, D., Klos, A., Chen, H., Acker, B., Bruckner, U.B., Nilsson, B., Gebhard, F., Lambris, J.D. and Huber-Lang, M. (2010) Molecular Intercommunication between the Complement and Coagulation System. Journal of Immunology, 185, 5628-5636. https://doi.org/10.4049/jimmunol.0903678

[9] Oikonomopoulou, K. and Ricklin, D. (2012) Interactions between Coagulation and Complement-Their Role in Inflammation. Seminars in Immunopathology, 34, 151-165. https://doi.org/10.1007/s00281-011-0280-x

[10] Angel, D.E., Lioyd, P., Carville, K. and Santamaria, N. (2011) The Clinical Efficacy of Two Semi-Quantitative Wound-Swabbing Techniques in Identifying the Causative Organisms in Infected Cutaneous Wounds. International Wound Journal, 8, 176-185. https://doi.org/10.1111/j.1742-481X.2010.00765.x

[11] Bonham, P.A. (2009) Swab Cultures for Diagnosis Wound Infections: A Literature Review and Clinical Guideline. Journal of Wound Ostomy and Continence Nursing, 36, 389-395. https://doi.org/10.1097/WON.0b013e3181aaef7f

[12] Forbes, B.A., Sahm, D.F. and Weissfeld, A.S. (2007) Bailey and Scott's Diagnostic Microbiology. 12th Edition, Mosby, Maryland Heights, MO, 108.

[13] Kamlage, B., Neuber, S., Bethan, B., Maldonado, S.G., Wagner-Golbs, A., Peter, E. and Schatz, P. (2018) Impact of Prolonged Blood Incubation and Extended Serum Storage at Room Temperature on the Human Serum Metabolome. Journal of $\mathrm{Me}$ tabolites, 8, 1-13. https://doi.org/10.3390/metabo8010006

[14] Scales, B. and Huffnagle, G. (2013) The Microbime in Wound Repair and Tissue Fibrosis. The Journal of Pathology, 229, 323-331. https://doi.org/10.1002/path.4118

[15] Nagoba, B., Raju, R., Wadher, B., Gandhi, R., Rao, A.K., Selkar, S. and Hartalkar, A. (2011) Citric Acid Treatment of Surgical Site Infections: A Prospective Open Study. Wound Practice and Research: Journal of the Australian Wound Management Association, 19, 82-86.

[16] Yin, H., Li, X., Hu, S., Liu, T., Yuan, B., Ni, Q., Lan, F., Luo, X., Gu, H. and Zheng, F. (2013) IL-33 Promotes Staphylococcus aureus-Infected Wound Healing in Mice. International Immunopharmacology, 17, 432-438.

https://doi.org/10.1016/j.intimp.2013.07.008 
[17] Rajan, S. (2012) Skin and Soft-Tissue Infections: Classifying and Treating a Spectrum. Cleveland Clinic Journal of Medicine, 79, 57-66. https://doi.org/10.3949/ccjm.79a.11044

[18] Alwan, M.J., Lafta, I.J. and Hamzah, A.M. (2011) Bacterial Isolation from Burn Wound Infections and Studying Their Antimicrobial Susceptibility. Kufa Journal for Veterinary Medical Sciences, 2, 121-131.

[19] Chen, H.M., Chi, H., Chiu, N.C. and Huang, F.Y. (2015) Kocuria kristinae: A True Pathogen in Pediatric Patients. Journal of Microbiology, Immunology and Infection, 48, 80-84. https://doi.org/10.1016/j.jmii.2013.07.001

[20] Horino, T., Shimamura, Y., Ogata, K., Inoue, K. and Terada, Y. (2016) Kocuria kristinae Septic Arthritis Associated with Infectious Endocarditis in a Hemodialysis Patients with Diabetic Mellitus: A Case Report and Literature Review. Renal Replacement Therapy, 2, 32-41. https://doi.org/10.1186/s41100-016-0041-3

[21] Ma, E.S., Wong, C.L., Lai, K.T., Chan, E.C., Yam, W. and Chan, A.C. (2005) Kocuria kristinae Infection Associated with Acute Cholecystitis. BMC Infectious Diseases, 5, 60-66. https://doi.org/10.1186/1471-2334-5-60

[22] Kandi, V., Palange, P., Vaish, R., Bhatti, A.B., Kale, V., Kandi, M.R. and Bhoomagiri, M.R. (2016) Emerging Bacterial Infection: Identification and Clinical Significance of Kocuria Spp. Cureus, 8, 73-81. https://doi.org/10.7759/cureus.731

[23] Shah, P., Ostwal, K., Jadhav, A. and Shaikh, N. (2015) Post Hysterectomy Wound Infection by Dermacoccus Nishinomiyaensis-A First Case Report in India. European Journal of Biomedical and Pharmaceutical Sciences, 2, 329-335.

[24] Valen, A. (2011) Characterization of Airborne Microorganism at National Theatre Subway Station. Master's Thesis, Norwegian University of Science and Technology, Gjøvik, Norway.

[25] Al-Ali, K.Y. (2016) Microbial Profile of Burn Wound Infections in Burn Patients, Taif, Saudi Arabia. Archives of Clinical Microbiology, 7, 1-9.

[26] Rashid, K.J., Babakir-Mina, M. and Abdilkarim, D.A. (2017) Characteristics of Burn Injury and Factors in Relation to Infection among Pediatric Patients. MOJ Gerontology and Geriatrics, 1, 1-13.

[27] Idomir, M., Pirau, R., Nemet, C. and Badea, M. (2012) Evaluation of Microbiological Spectrum of Burn Wound Infections. Bulletin of the Transilvania University of Brasov, 5, 7-11.

[28] Datta, S., Ghosh, T., Sarkar, D., Tudu, N.K., Chatterjee, T.K. and Jana, A. (2016) Bacteriological Profile of Burn Wounds and Their Antibiotic Susceptibility Pattern in a Tertiary Care Hospital. International Journal of Scientific Study, 4, 141-145.

[29] Orban, C. (2012) Diagnostic Criteria for Sepsis in Burns Patients. Chirurgia (Bucur), 107, 697-700.

[30] Rafail, S., Kourtzelis, I., Foukas, P.G., Markiewski, M.M., De Angelis, R.A., Guariento, M., Ricklin, D., Grice, E.A. and Lambris, J.D. (2015) Complement Deficiency Promotes Cutaneous Wound Healing in Mice. The Journal of Immunology, 194, 1285-1291. https://doi.org/10.4049/jimmunol.1402354

[31] Triplett, A. and Hurwitz, A.A. (2014) Complement and Adaptive Immunity: Roles for the Anaphylatoxins C3a and C5a in Regulating Tumor Immunity. International Trends in Immunity, 2, 78-82.

[32] Jang, J.H., Liang, D., Kido, K., Sun, Y., Clark, D.J. and Brennan, T.J. (2011) Increased Local Concentration of Complement C5a Contributes to Incisional Pain in Mice. Journal of Neuroinflammation, 8, 1-17. 
https://doi.org/10.1186/1742-2094-8-80

[33] Morris, A.C., Kefala, K., Wilkinson, T.S., Dhaliwal, K., Farrell, L., Walsh, T., Mackenzie, S.J., Reid, H., Davidson, D.J., Haslett, C., Rossi, A.G., Sallenave, J.M. and Simpso, A.J. (2009) C5a Mediates Peripheral Blood Neutrophil Dysfunction in Critically III Patients. American Journal of Respiration and Critical Care Medicine, 180, 19-28. https://doi.org/10.1164/rccm.200812-1928OC

[34] Cazander, G., Jukema, G.N. and Nibbering, P.H. (2012) Complement Activation and Inhibition in Wound Healing. Clinical and Developmental Immunology, 2012, Article ID: 534291. https://doi.org/10.1155/2012/534291 